\title{
THE NORTHERN BOUNDARY OF THE DESERT TORTOISE RANGE ON THE NEVADA TEST SITE
}

Kurt R. Rautenstrauch

Gregory A. Brown

Rod G. Goodwin

Project Scientists

REVIEWED BY

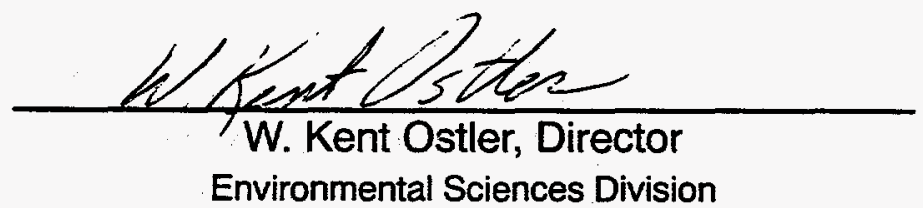

Environmental Sciences Division

This Document is UNCLASSIFIED

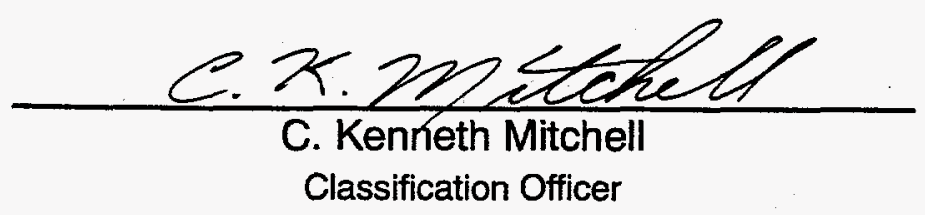

This work was performed by EG\&G/EM for the United States Department of Energy under Contract Number DE-AC08-93NV11265. 


\section{DISCLAIMER}

This report was prepared as an account of work sponsored by an agency of the United States Government. Neither the United States Government nor any agency thereof, nor any of their employees, make any warranty, express or implied, or assumes any legal liability or responsibility for the accuracy, completeness, or usefulness of any information, apparatus, product, or process disclosed, or represents that its use would not infringe privately owned rights. Reference herein to any specific commercial product, process, or service by trade name, trademark, manufacturer, or otherwise does not necessarily constitute or imply its endorsement, recommendation, or favoring by the United States Government or any agency thereof. The views and opinions of authors expressed herein do not necessarily state or reflect those of the United States Government or any agency thereof. 


\section{DISCLAIMER}

Portions of this document may be illegible in electronic image products. Images are produced from the best available original document. 


\section{Abstract}

A study was conducted in 1993 to more accurately define the northern boundary of the range of desert tortoises (Gopherus agassizii) on the Nevada Test Site. Eighty-six transects totalling $338.2 \mathrm{~km}$ were walked along this boundary and 53 tortoise sign were recorded. Tortoise sign was found all along the northern edge of Jackass and Frenchman flats. Sign was found north of those valleys only in the Calico Hills at the south end of Topopah Valley and in the CP Hills at the extreme southern end of Yucca Flat. A revised map of the range of desert tortoises on NTS is presented. This information can be used by the U.S. Department of Energy to determine whether activities conducted along or near this boundary will affect desert tortoises. 


\section{Acknowledgements}

The following biologists from EG\&G Energy Measurements (EG\&G/EM) conducted searches for tortoises: A. M. Ambos, M. M. Annear, S. R. Blomquist, T. E. Bond, T. Burke, C. A. Callison, T. Campbell, M. W. Fariss, A. E. Gabbert, K. L. Herndon, E. A. Holt, M. W. Janis, S. Leskie, L. L. Lewis, D. H. Livingston, K. D. Minniefield, H. Muller, K. R. Naifeh, S. M. Schultz, G. T. Sharp, C. L. Sowell, L. J. Taylor, M. D. Walo, and K. K. Zander.

D. L. Rakestraw and W. K. Ostler provided administrative support for this project.

S. R. Blomquist, R. C. Furlow, J. M. Mueller, W. K. Ostler, T. P. O'Farrell, D. L. Rakestraw, and C. A. Wills provided editorial comments.

J. D. Pickus, S. L. Geherty, D. C. Lattimore, and J. K. Donovan, EG\&G/EM Remote Sensing Laboratory, assisted in analyzing the data and producing maps. 


\section{Contents}

Abstract $\ldots \ldots \ldots \ldots \ldots \ldots \ldots \ldots \ldots \ldots \ldots \ldots \ldots \ldots \ldots$

Acknowledgements $\ldots \ldots \ldots \ldots \ldots \ldots \ldots \ldots \ldots \ldots \ldots$ ii

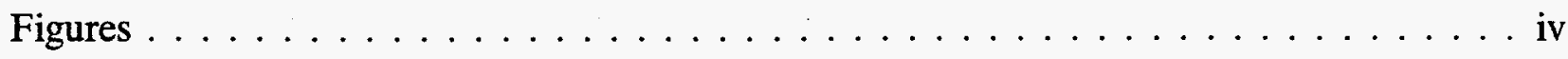

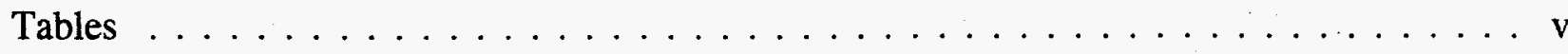

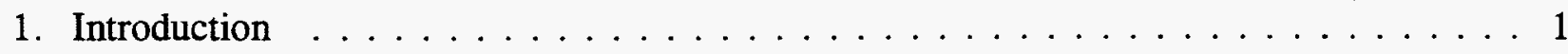

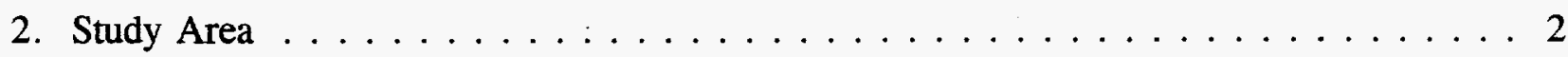

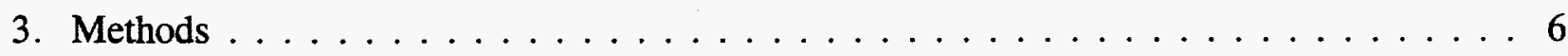

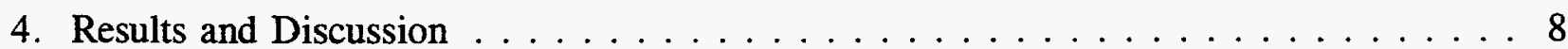

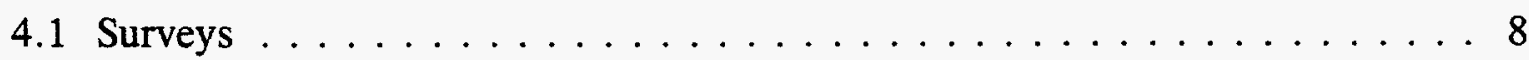

4.2 Northern Boundary . . . . . . . . . . . . . . . . 10

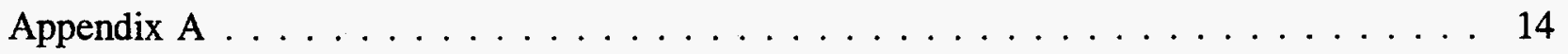

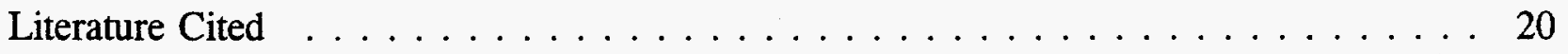




\section{Figures}

1. Major topographic features on the Nevada Test Site ............ 3

2. Changes in elevation from the southern end of the Nevada Test Site in Mercury Valley through Frenchman and Yucca flats $\ldots \ldots \ldots \ldots \ldots$

3. Distribution of vegetation associations on the Nevada Test Site $\ldots \ldots \ldots$

4. Transects walked and sign of desert tortoises $(\bullet)$ found on the Nevada Test Site during $1993 \ldots \ldots \ldots \ldots \ldots \ldots \ldots$

5. The northern boundary of the range of the desert tortoise on the Nevada Test Site 11 


\section{Tables}

1. Distance walked and sign of desert tortoises found per $\mathrm{km}$ within six 100-m elevation zones on the Nevada Test Site in $1993 \ldots \ldots \ldots \ldots$ 


\section{Introduction}

The desert tortoise (Gopherus agassizii) is the only animal species commonly found on the Nevada Test Site (NTS) that is listed under the Endangered Species Act as threatened or endangered. Desert tortoises are found only in the southern part of NTS, which is managed by the U.S. Department of Energy, Nevada Operations Office (DOE/NV). The Act requires DOE/NV to consult with the U.S. Fish and Wildlife Service (FWS) if an activity may affect desert tortoises. To determine whether or not an activity may affect tortoises, DOE/NV must know if an activity will occur within the range of the tortoise on NTS.

To describe the range and relative abundance of desert tortoises on NTS, EG\&G/EM (1991) summarized information on tortoise sign found along $1,191 \mathrm{~km}$ of transects walked on and adjacent to NTS during 1981-1985. That report concluded that desert tortoises are found about as far north as the crest of Massachusetts Mountain and the CP Hills on the east side of NTS, and to the southern boundary of Area 29 at the western edge of NTS (EG\&G/EM, 1991:26). However, because few transects were walked in some areas, this boundary could not be defined precisely everywhere.

To more accurately define the range of the desert tortoise on NTS, surveys for desert tortoises were conducted in 1993 along the northern boundary identified in EG\&G/EM (1991). This report contains a summary of the results of those surveys and a revised map of the northern boundary of the range of the desert tortoise on NTS. 


\section{Study Area}

The NTS is located in Nye County in southwestern Nevada (Figure 1). The physiography, geology, climate, and vegetation of this site are described by Beatley $(1975,1976)$, O'Farrell and Emery (1976), and EG\&G/EM (1991).

The southern portion of NTS is within the Mojave Desert and the northern portion is within the Great Basin Desert. The boundary of the range of desert tortoises on NTS occurs within the transition between these two deserts. This transition begins approximately in the northern half of Jackass and Frenchman flats and extends through the next series of valleys to the north: Topopah Valley, Mid Valley, Yucca Flat, and Plutonium Valley (Figure 1).

The elevation of the valley floors increases substantially from south to north in this transition zone. For example, the elevation on the playa in Frenchman Flat is $939 \mathrm{~m}$. The elevation $12 \mathrm{~km}$ to the north on the playa in Yucca Flat is $1,195 \mathrm{~m}$ (Figure 2). The elevation at the outlet of Jackass Flat is about $900 \mathrm{~m}$ and the outlets of the two basins to the north, Topopah and Mid Valleys, are about $1,300 \mathrm{~m}$. Associated with this increase in elevation is an increase in precipitation and a decrease in temperature (Beatley, 1975)

Beatley (1976) identified two plant communities in this transition: those on upper bajadas above the Mojave Desert communities and those on lower bajadas and floors of closed basins. On the upper bajadas, blackbrush (Coleogyne ramosissima) is the dominant species (Figure 3). It occurs in mixed stands with creosotebush (Larrea tridentata) and other Mojave Desert species at elevations between 1,200 and $1,370 \mathrm{~m}$ and often in nearly pure stands between 1,370 and $1,500 \mathrm{~m}$. In these areas, shrub coverage is high (45-51\%), the diversity of plant species is low, and herbaceous species are uncommon (Beatley, 1976).

On the lower bajadas and floors of closed basins in this region, such as Frenchman and Yucca flats, drainage of cold air at night creates a climate too cold for the Mojave Desert plant associations commonly found at similar elevations in open basins (Beatley, 1975, 1976). The floors of these closed basins usually are covered by stands of hopsage (Grayia spinosa) and box thorn (Lycium spp.) (Figure 3). This association is confined to elevations between 1,220 and $1,525 \mathrm{~m}$. Shrub coverage varies from 32 to $37 \%$. Herbaceous species are not as common as in the Mojave Desert communities, but they are more abundant than on the upper bajadas (Beatley, 1976). 


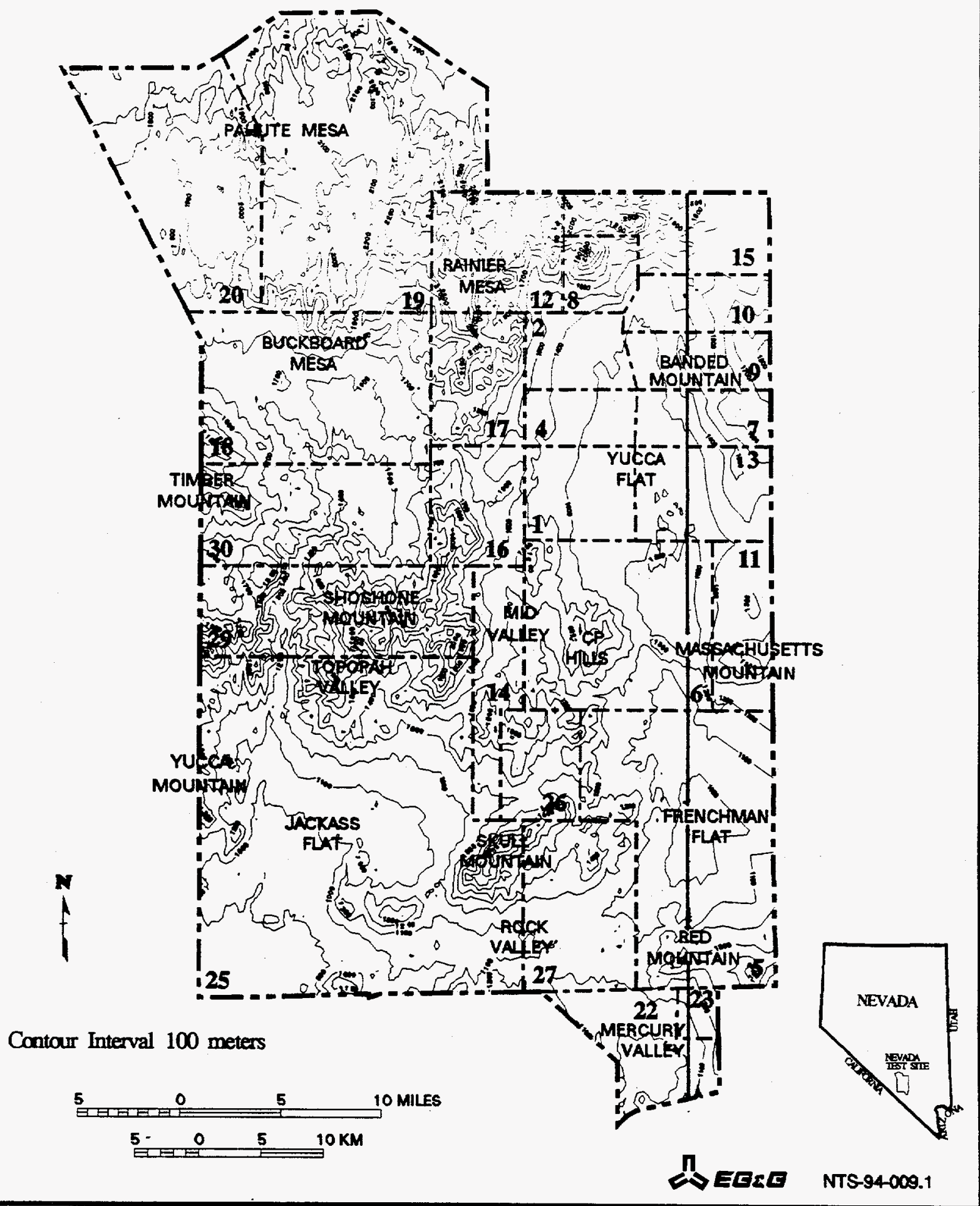

Figure 1. Major topographic features on the Nevada Test Site. The line near the eastern edge of the map is the transect along which changes in elevation are shown in Figure 2. 


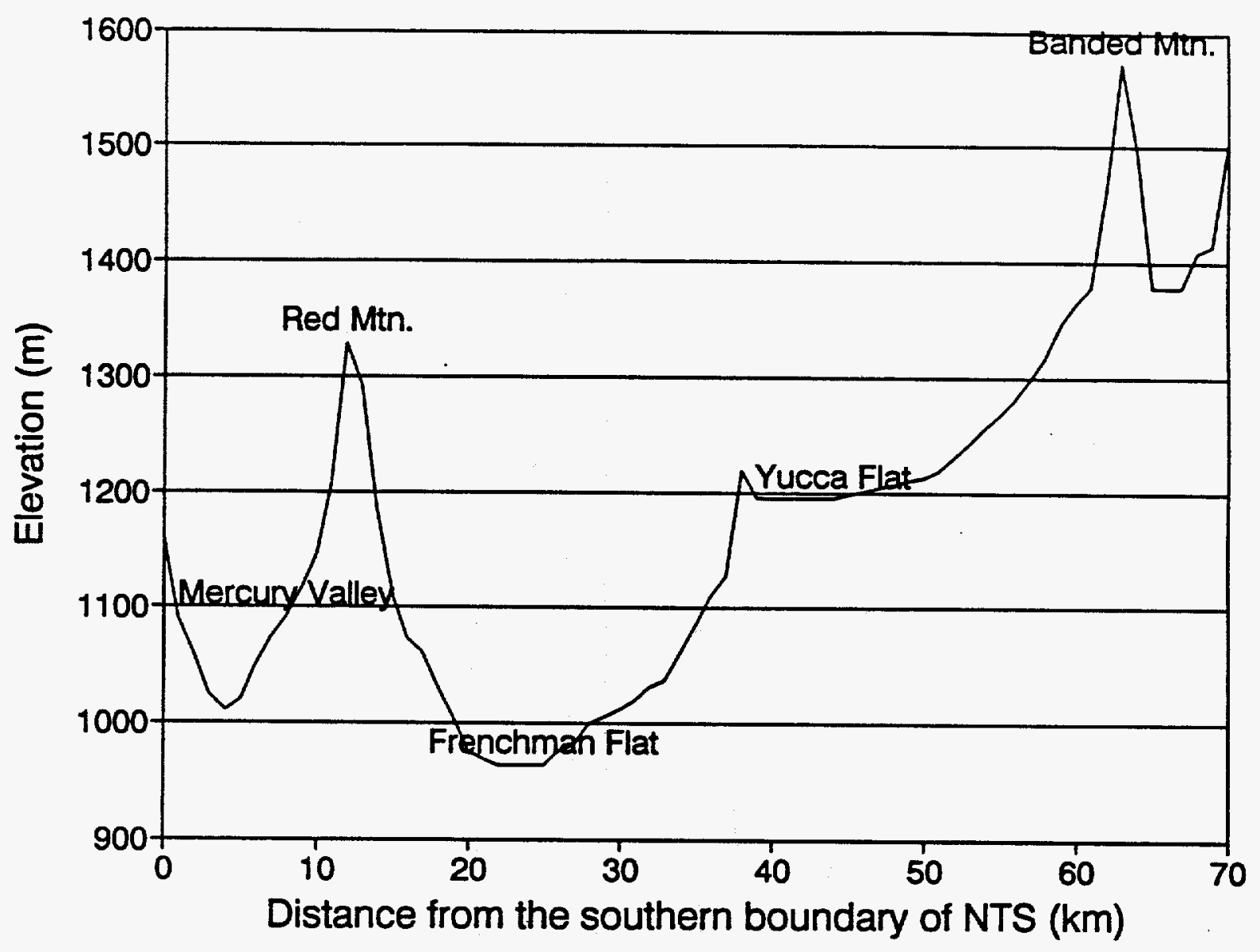

Figure 2. Changes in elevation from the southern end of the Nevada Test Site in Mercury Valley through Frenchman and Yucca flats. The line along which elevation was measured is shown in Figure 1. 


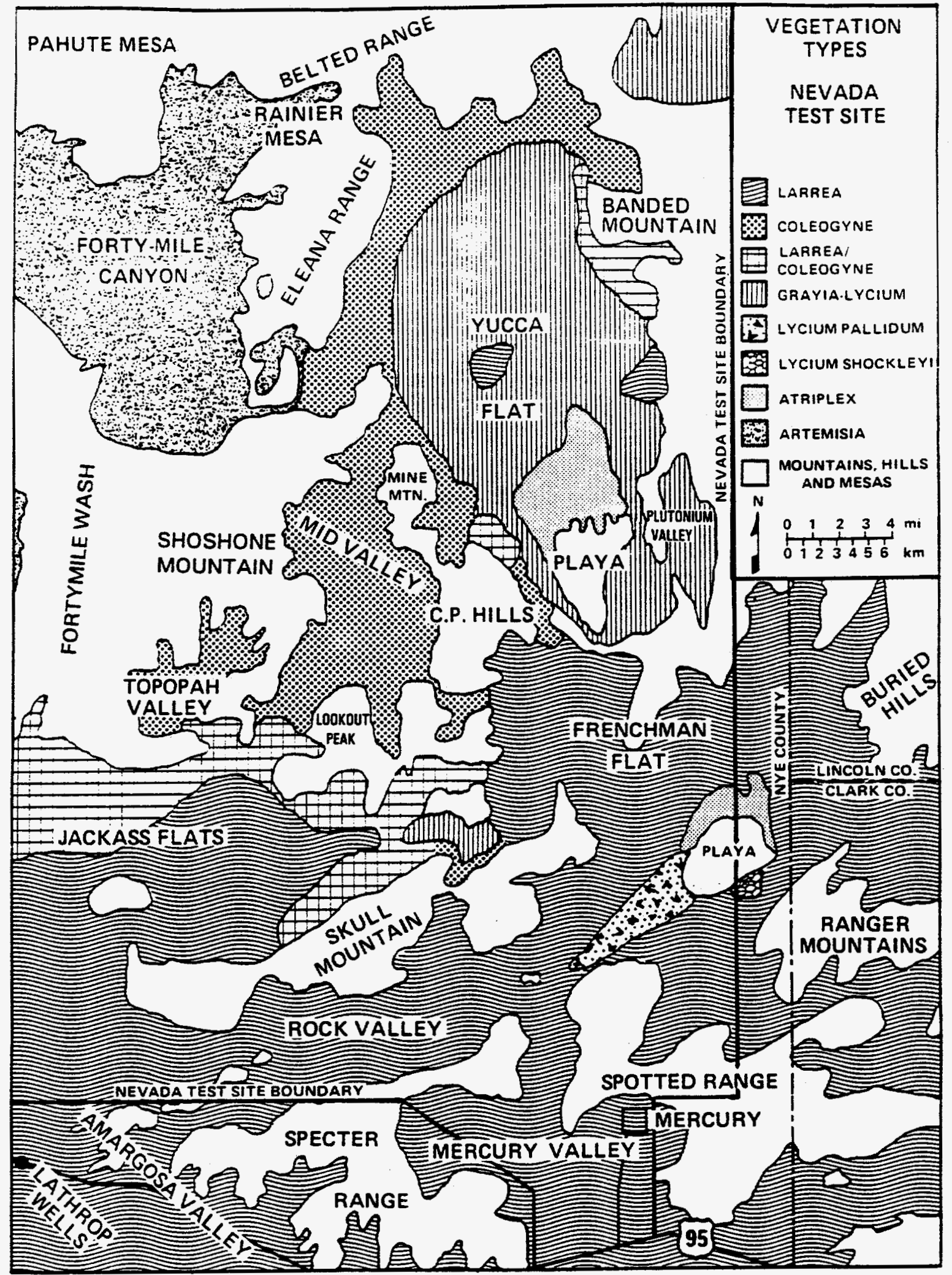

Figure 3. Distribution of vegetation associations on the Nevada Test Site (from O'Farrell and Emery, 1976). 


\section{Methods}

During June-August 1993, biologists searched for sign of desert tortoises along and just north of the boundary of the known range of this species on NTS. Specific locations that had creosotebush, rock or caliche outcrops, large washes, deep alluvial soils, or other physiographic features believed to be associated with the presence of desert tortoises were searched.

Three biologists spaced $\leq 10 \mathrm{~m}$ apart searched for tortoise sign along 30 -m-wide, meandering transects. Each transect started and ended at about the same point. The transects varied in length and usually followed contours or topographic features. Transect paths and tortoise sign were recorded on U.S. Geological Survey topographic maps of 1:24,000 scale. Sign was classified as living tortoise, tortoise carcass, burrow, scat, or egg. Only burrows with the shape typical of those constructed by tortoises (i.e., flat floor and round roof) were recorded. More than one sign found in a $1-\mathrm{m}^{2}$ area was recorded as one observation.

A single biologist per transect has been used in most previous studies designed to find tortoise sign (Karl, 1981; Luckenbach, 1982; EG\&G/EM, 1991). Groups of three biologists were used for this study to increase the probability of finding sign. To evaluate the efficacy of using three people, a $1.5-\mathrm{km}$ transect was walked near the northern boundary in northeastern Jackass Flats where tortoises had been found in the past. Two tortoises in two burrows were found. Because the goal of these transects was to detect the presence of tortoises, it was concluded that this method was adequate in areas with low densities of tortoises.

Locations of transects and tortoise sign were digitized and entered into a computerized Geographic Information System. This system was used to calculate the length of each transect and distance walked within six 100-m elevation zones. A Chi-Square goodness-of-fit test was used to evaluate the assumption that sign of tortoises was found in equal abundance among the four elevation zones where $>10 \mathrm{~km}$ were walked.

Based on the location of sign found during this study, the results reported in EG\&G/EM (1991), and the following three assumptions, a zone defining the northern boundary of the range of the desert tortoise on NTS was mapped. The southern edge of that zone represents the line below which tortoises are known to occur. The northern edge is the line above which it is believed that tortoises are very rare or absent.

The first assumption used to define this boundary was that tortoises are very rare or not found in large $\left(>1 \mathrm{~km}^{2}\right)$ stands of blackbrush where creosotebush, bursage (Ambrosia dumosa), and other shrubs common in the Mojave Desert are rare or absent. On NTS 
during 1981-1985, only one sign of desert tortoises was found on $34.9 \mathrm{~km}$ of single-person transects in the blackbrush association (EG\&G/EM, 1991). That sign, a scat, was found on the side of a hill in upper Barren Wash in an area with a mix of creosotebush and blackbrush. Karl (1981) found no sign along $5 \mathrm{~km}$ of single-person transects in blackbrushdominated areas in Nye County, Nevada. She found that tortoise abundance was negatively correlated with the predominance of blackbrush. Schneider et al. (1982) walked about $10 \mathrm{~km}$ of single-person transects in blackbrush communities near Blue Diamond, Nevada, and found no sign of tortoises.

Second, it was assumed that tortoises are very rare or not found in the box thorn-hopsage association found in enclosed valley bottoms. No sign was found along $7 \mathrm{~km}$ of singleperson transects on NTS during 1981-1985. This association occurs in cold-air drainages and the soils tend to have a very high content of clay and salts that probably are disadvantageous to tortoises.

Third, it was assumed that tortoises are uncommon above $1,500 \mathrm{~m}$ and are very rare or not found above $1,600 \mathrm{~m}$. During 1981-1985, only one sign was found on $11 \mathrm{~km}$ of transects walked at elevations $>1,500 \mathrm{~m}$ (EG\&G/EM, 1991). This sign, found at $1,570 \mathrm{~m}$, is one of the highest elevations of tortoise sign reported in the literature. The only reports of tortoise sign found at higher elevations that the authors of this report are aware of are in Luckenbach (1982) and Barrett and Johnson (1990). Luckenbach (1982:12) reported that one live tortoise and one carcass were found at 2,225 and 2,256 m, respectively, in Death Valley National Monument. Both tortoises may have been carried to those elevations by humans or predators. Barrett and Johnson (1990:7) mentioned that tortoises have been found as high as $1,615 \mathrm{~m}$ on the eastern slope of the Santa Catalina Mountains in southern Arizona. 


\section{Results and Discussion}

\subsection{Surveys}

A total of $338.2 \mathrm{~km}$, covering $1014.6 \mathrm{ha}$, was surveyed. Eleven live tortoises, fourteen burrows, eight carcasses, and twenty scat were found (Figure 4).

Elevation along the transects ranged from a low of $1,140 \mathrm{~m}$ in Fortymile Canyon to a high of $1,675 \mathrm{~m}$ in the Calico Hills. Sign was found at elevations from 1,145 to $1,530 \mathrm{~m}$. Sign found per $\mathrm{km}$ walked was highest from 1,100 to $1,199 \mathrm{~m}(0.77 \mathrm{sign} / \mathrm{km})$ and lowest from 1,600 to $1,699 \mathrm{~m}(0 \mathrm{sign} / \mathrm{km})$, but the sample sizes for these elevation zones was very small (Table 1). There was no difference in amount of sign found per $\mathrm{km}$ walked within the four 100 -m elevation zones between 1,200 and $1,599 \mathrm{~m}\left(P=0.11, X^{2}=6.08,3 \mathrm{df}\right)$.

On the western edge of NTS in Fortymile Canyon, one tortoise burrow was found on a 4.4$\mathrm{km}$-long transect (no. 2) $2.4 \mathrm{~km}$ north of the Area 25-29 boundary (Appendix A1). No sign was found on $16.1 \mathrm{~km}$ (transects 1, 3-6) elsewhere in that canyon.

To the east of Fortymile Canyon, five sign were found along $8.4 \mathrm{~km}$ (transects 12 and 14) in the northern slopes of the Calico Hills at the south end of Topopah Valley (Appendix A2). No sign was found along $34.6 \mathrm{~km}$ of other transects $(7-11,13,15-17)$ in this valley.

East of the entrance to Topopah Valley in the northeast corner of Jackass Flat, 13 sign were found along $63.0 \mathrm{~km}$ of transects (18-23, 28-36) (Appendix A2). Most of these sign, including five live tortoises, were found in or near a small canyon at the southeast end of Shoshone Mountain about $4 \mathrm{~km}$ east of the entrance to Topopah Valley (transects 19, 28-31). One scat was found near Saddle Road about $3 \mathrm{~km}$ south of the divide between Jackass Flat

Table 1. Distance walked and sign of desert tortoises found per $\mathrm{km}$ within six $100-\mathrm{m}$ elevation zones on the Nevada Test Site in 1993.

\begin{tabular}{ccc}
\hline Elevation $(\mathrm{m})$ & Km walked & Sign $/ \mathrm{km}$ \\
\hline $1,100-1,199$ & 5.2 & 0.77 \\
$1,200-1,299$ & 75.0 & 0.11 \\
$1,300-1,399$ & 113.7 & 0.11 \\
$1,400-1,499$ & 109.0 & 0.22 \\
$1,5000-1,599$ & 32.7 & 0.15 \\
$1,600-1,699$ & 2.5 & 0 \\
\hline
\end{tabular}




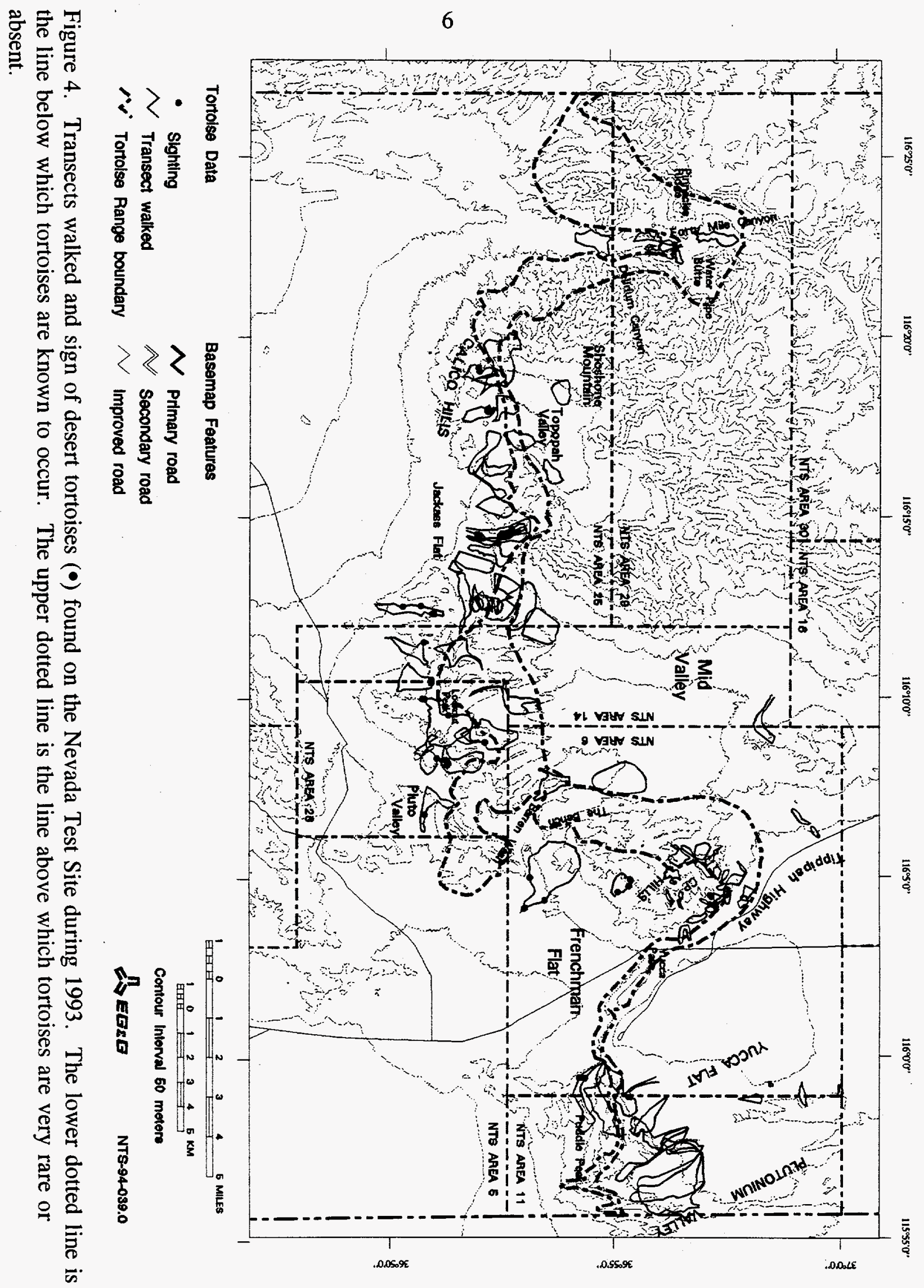


and Mid Valley (transect 36), but no sign was found along $18.1 \mathrm{~km}$ of transects (20-23) closer to that divide.

Twenty-six sign were found along $67.4 \mathrm{~km}$ of transects $(37-40,42-47,69-70,86)$ in the south-draining canyons and hills such as Lookout Peak that separate Mid Valley from Jackass Flat, Wahmonie Flat, Pluto Valley, and Frenchman Flat (Appendices A3 and A4).

No sign was found along $24.4 \mathrm{~km}$ (transects $24-27,41$ ) on the slopes draining into Mid Valley or in the bottom of that valley (Appendices A3 and A4).

There were $41.2 \mathrm{~km}$ of transects (50-68) searched in the canyons and bajadas on the north side of CP Hills that drain into Yucca Flat (Appendix A4). Six sign of tortoises, including two live tortoises, were found in a small canyon $2.5-3 \mathrm{~km}$ north-northeast of the NTS Control Point. No sign was found along $3.4 \mathrm{~km}$ of transects (48-49) in an isolated patch of creosote bush near the intersection of Tippipah Highway and Mine Mountain Road.

Two sign were found along $15.2 \mathrm{~km}$ (transects 84 and 85 ) just west of Puddle Peak in a canyon that drains into Frenchman Flat (Appendix A5). No sign was found on $21.4 \mathrm{~km}$ of transects (80-83) on and just north of the north-facing slopes of French and Puddle peaks that drain into the southeast corner of Yucca Flat. Nor was sign found on $32.6 \mathrm{~km}$ of transects in the south end of Plutonium Valley (transects 75-79) or along $6.1 \mathrm{~km}$ in isolated patches of creosotebush to the west of Orange Blossom Road on the east side of Yucca Flat (transects 71-74) (Appendix A5).

\subsection{Northern Boundary}

The following discussion is a description of the northern boundary of the desert tortoise range on NTS, starting at the western edge of that site. Figure 5 shows the northern edge of the boundary zone mapped for this study, beyond which tortoises are very rare or absent.

West of Fortymile Canyon, tortoises are found at least as far north as the Yucca Wash drainage. At least seven tortoises have been found $\leq 1.5 \mathrm{~km}$ north of Yucca Wash during tortoise studies for the Yucca Mountain Site Characterization Office. It is unknown how far north tortoises are found there, but they probably are not found on or north of the $>1,800-\mathrm{m}$ Pinnacles Ridge, 3-6 km north of Yucca Wash.

Within Fortymile Canyon, the range of the tortoise extends north 3-6 km beyond the boundaries of Areas 25 and 29 (Appendix A1). At about this point the vegetation changes in the bottom of the canyon. Creosotebush, bursage, and other Mojave Desert species common further south reach their northern limit here. Bitterbrush (Purshia tridentata) begins to appear and becomes a common species further north. The slopes throughout the southern end of this canyon are dominated by a mix of creosotebush and blackbrush. Although the slopes and side canyons surrounding Fortymile Canyon were not searched, tortoises probably are found to elevations of at least $1,500 \mathrm{~m}$. 


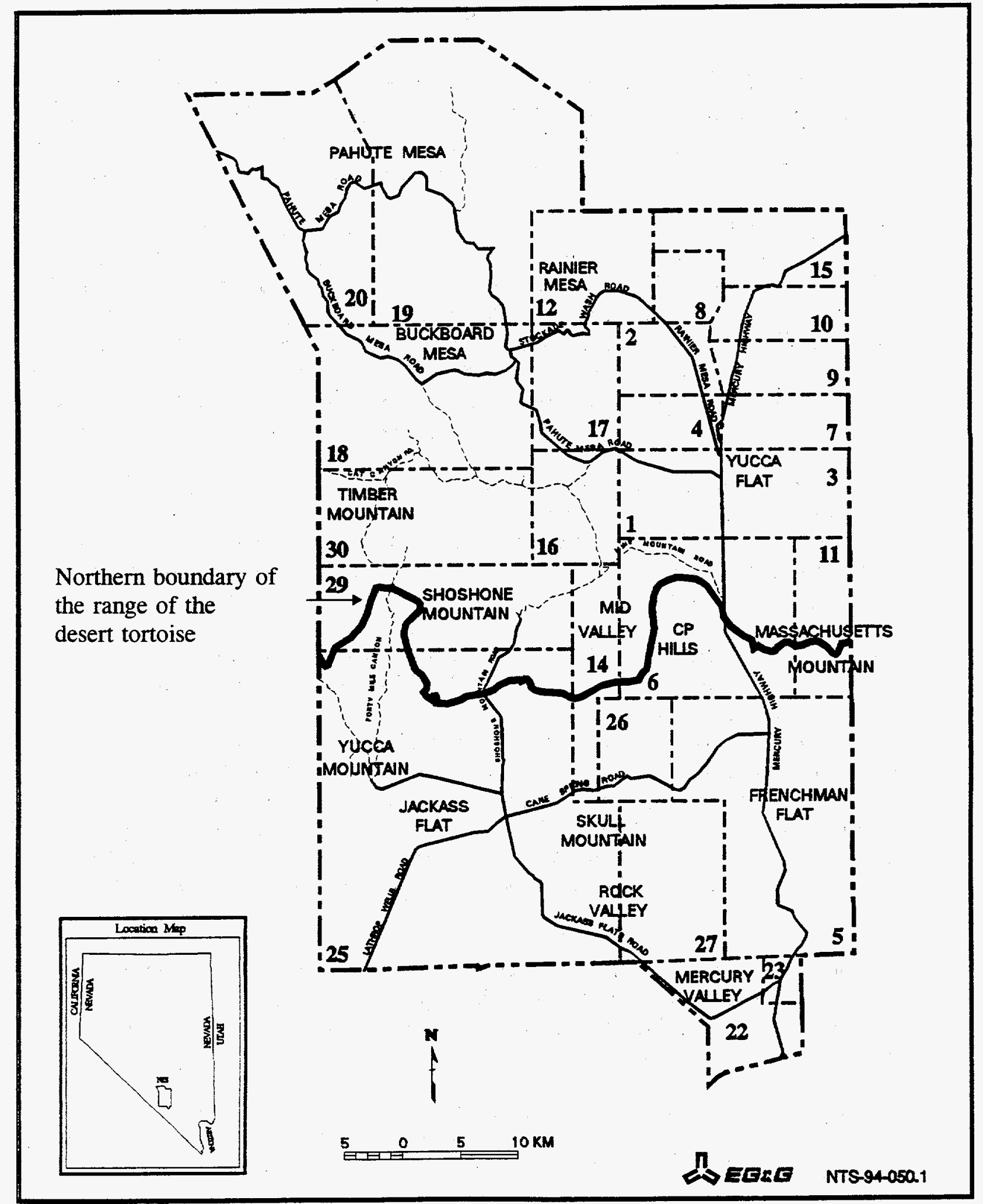

Figure 5. The northern boundary of the range of the desert tortoise on the Nevada Test Site. 
East of Fortymile Canyon, tortoises are found at least as far north as the north slopes of the Calico Hills at the south end of Topopah Valley (Appendix A2). This area has a mix of vegetation dominated by creosotebush and blackbrush. The rest of Topopah Valley is covered by almost pure stands of blackbrush and probably has very few or no tortoises.

Tortoises are found in the northeast corner of Jackass Flat almost to Mid Valley (Appendix A2). Sign was found about $3 \mathrm{~km}$ south of the divide separating those two valleys during this study and 5-8 km south of that divide during searches conducted in 1987-1990 (EG\&G/EM, 1991:17). The vegetation changes from a mixture of blackbrush and creosotebush common in northern Jackass Flat to the pure stands of blackbrush found throughout Mid Valley at an elevation of about $1,430 \mathrm{~m}, 2-3 \mathrm{~km}$ south of the divide between those valleys. The authors of this report do not know of any tortoises or tortoise sign that have ever been found in Mid Valley or the drainages flowing into that valley.

East of Jackass Flat, the boundary of the desert tortoise range crosses through Lookout Peak and the other mountains to the south and east of Mid Valley (Appendices A3 and A4). Sign of tortoises was relatively common along the south-draining slopes of those hills and in Nielsen and Barren washes, the major drainages in this area. Tortoises may also occur on the north-draining slopes of these hills; however, none were found during this study.

East of Mid Valley, tortoises are common on the south side of the CP Hills in the northwest corner of Frenchman Flat (EG\&G/EM, 1991). The two tortoises and scat found on the north side of the CP Hills (Appendix A4) are the first sign of tortoises found in the Yucca Flat watershed that the authors are aware of. Although tortoises probably occur elsewhere in this part of CP Hills, they seem to be very uncommon; no sign was found along about $40 \mathrm{~km}$ of other transects in this area. The two tortoises found probably were near the northern extreme of the tortoise range in these hills. The slopes and extreme upper bajadas in this area have a mix of blackbrush and creosotebush. Further downhill, about $1 \mathrm{~km}$ north of the canyon where the tortoises were found, at about Tippipah Highway, the vegetation changes to the box thorn-hopsage association.

East of the CP Hills, tortoises probably occur on or just south of CP Hogback, but not to the north. The playa in Yucca Flat extends to within $500 \mathrm{~m}$ of the northern base of CP Hogback. At this point, there is a sparse box thorn-hopsage association growing on saline soils.

East of CP Hogback, the boundary of the desert tortoise range runs along the crest of Massachusetts Mountain, which separates Frenchman Flat from Yucca Flat and Plutonium Valley. Tortoise sign was found in the lower, south-draining foothills of Massachusetts Mountain during 1993 (Appendix 5) and during searches conducted in 1987-1990 (EG\&G/EM, 1991:34). Those south-draining slopes and valleys have a creosotebush vegetation association. No sign was found on the north-draining slopes of this mountain or in Plutonium Valley, and tortoises probably are rare or absent there. These north-draining 
slopes at the south end of Plutonium Valley are covered with blackbrush, with some creosotebush in the upper drainages, and the valley bottom is in the box thorn-hopsage association.

In summary, tortoises are found on NTS to the northern edges of Jackass Flat; Frenchman Flat; and the small valleys, Wahmonie Flat and Pluto Valley, that separate them. Tortoises also are found on some slopes just to the north of those valleys, at least in the Calico and CP hills, but they are rare or not found further north in Topopah Valley, Mid Valley, Yucca Flat, Plutonium Valley, or on the other hills surrounding those valleys.

The revised northern boundary described in this report differs slightly from the boundary presented in EG\&G/EM (1991:25). Topopah, Mid, and Plutonium valleys were omitted from the range of the desert tortoise in this report and the southern end of Fortymile Canyon and the northern slopes of the CP Hills were included.

DOE/NV can use this information to determine whether or not proposed construction activities may affect the desert tortoise. The determination that a DOE/NV activity may affect this species is based primarily on the presence or absence of tortoises in and adjacent to sites to be disturbed. Therefore, activities conducted to the north of the border in Figure 5 usually will not affect desert tortoises and consultation with FWS may not be required. Activities on or south of the border in Figure 5 may affect desert tortoises and consultation may be required. 


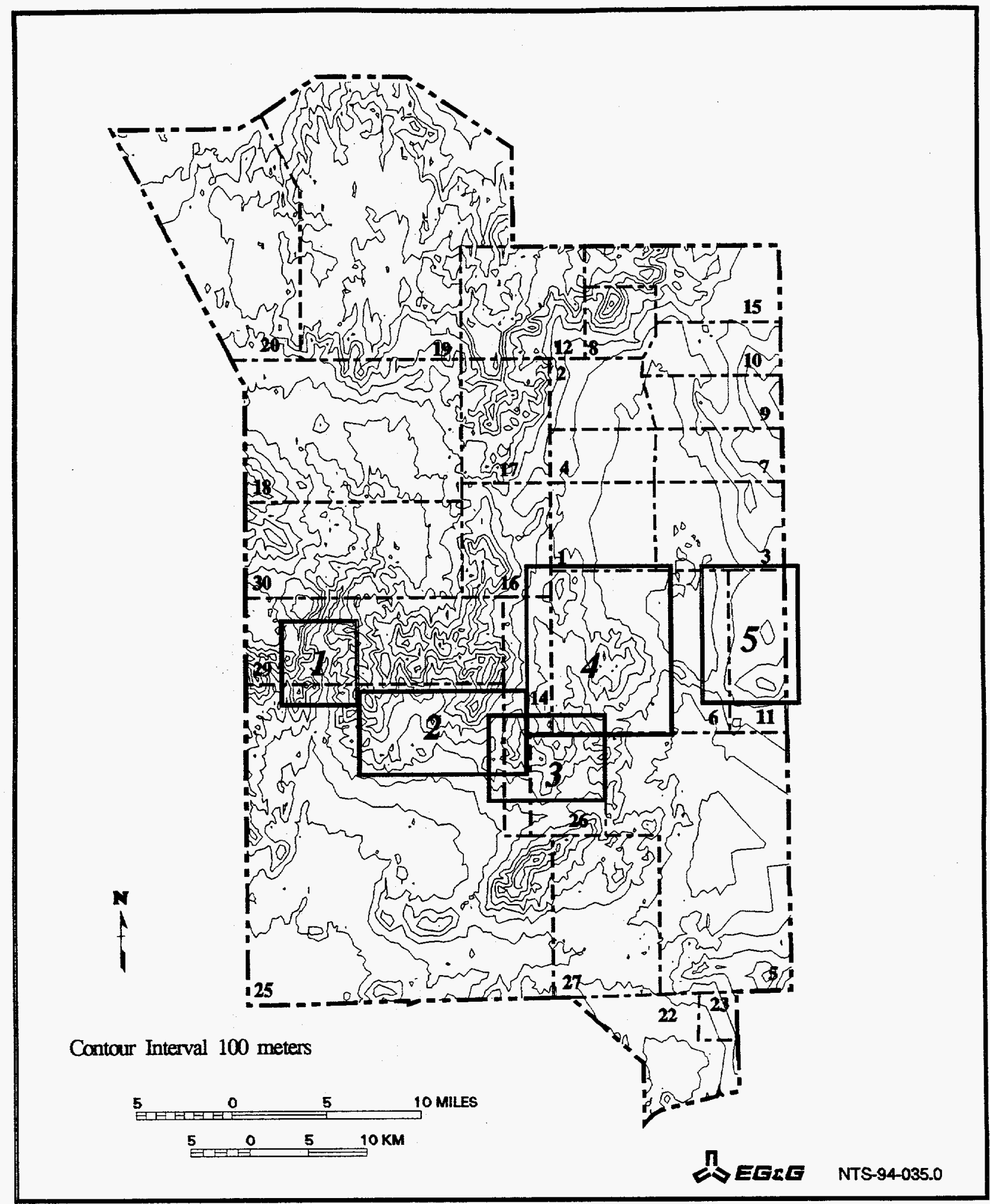

Appendix A. Boundaries of the five maps in Appendix A showing the transects walked and desert tortoise sign found on the Nevada Test Site during 1993. 


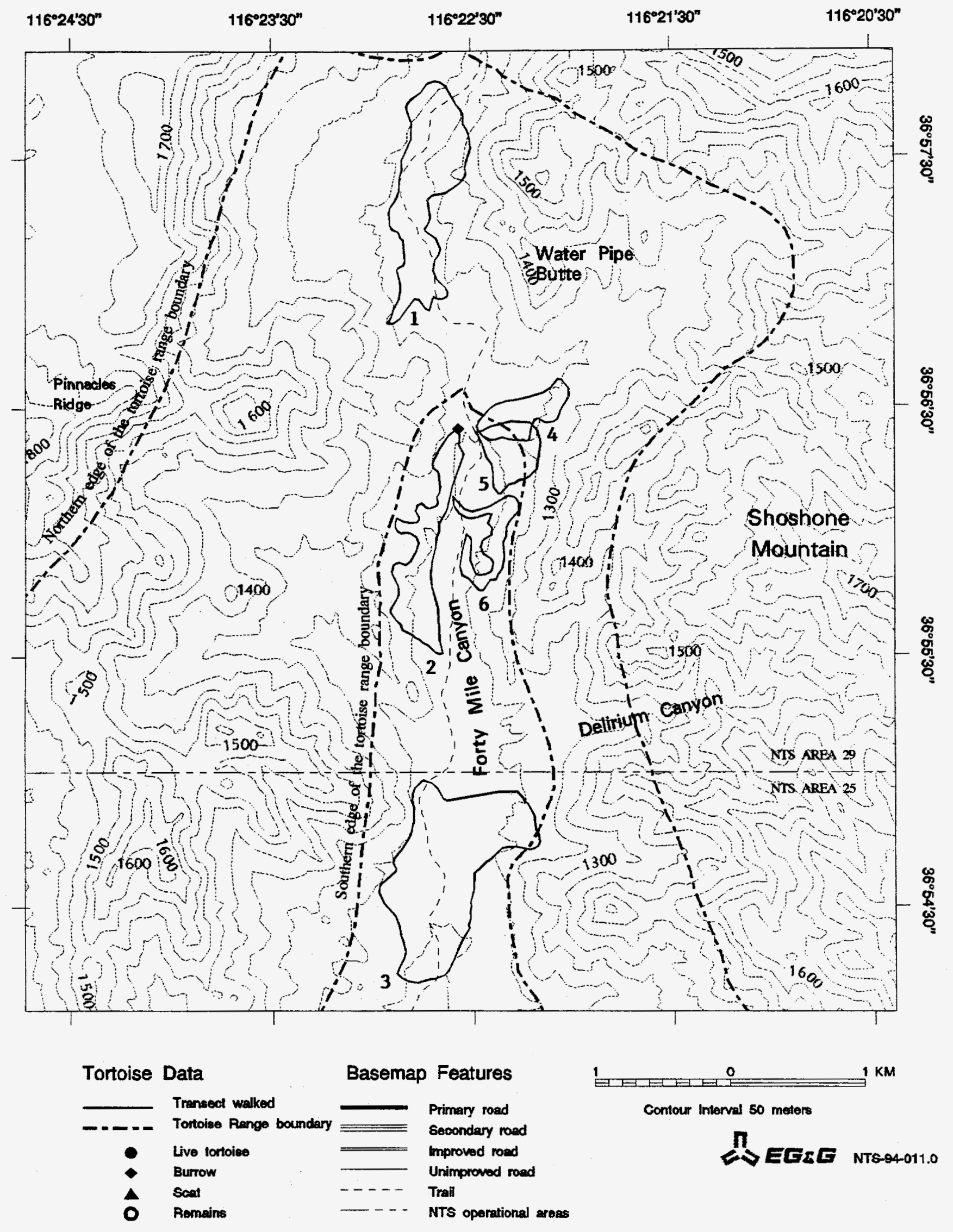

Appendix A1. Transects walked and desert tortoise sign found in Fortymile Canyon during 1993. Numbers adjacent to transects are the transect numbers referenced in the text. 


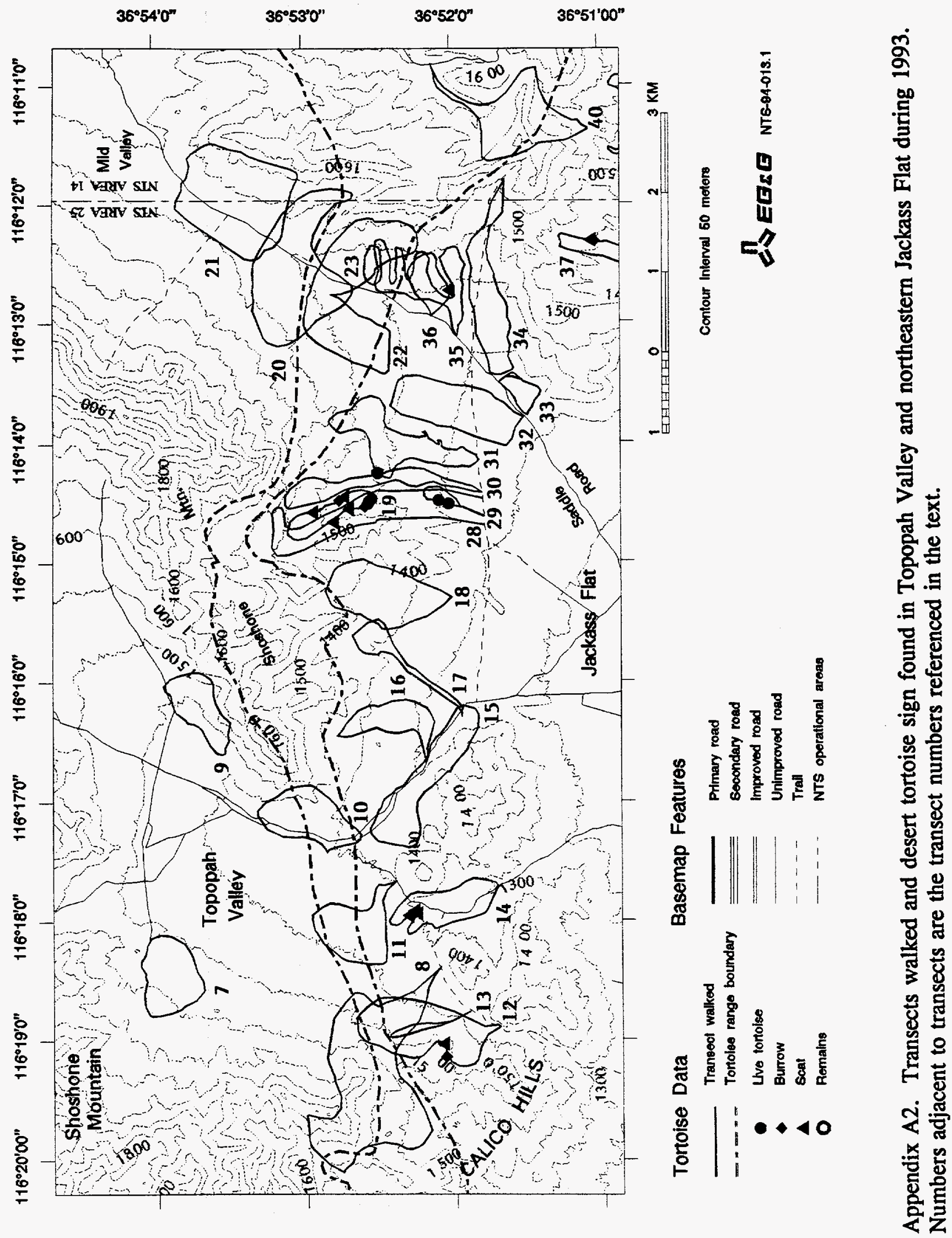




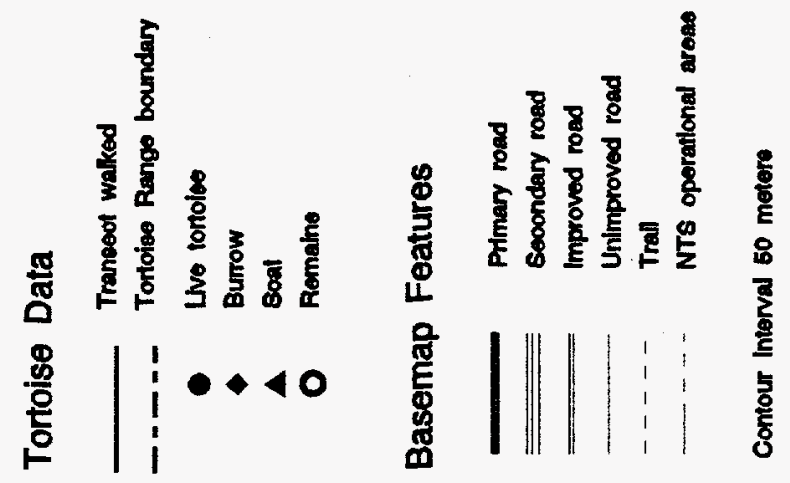

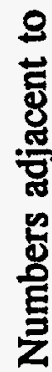

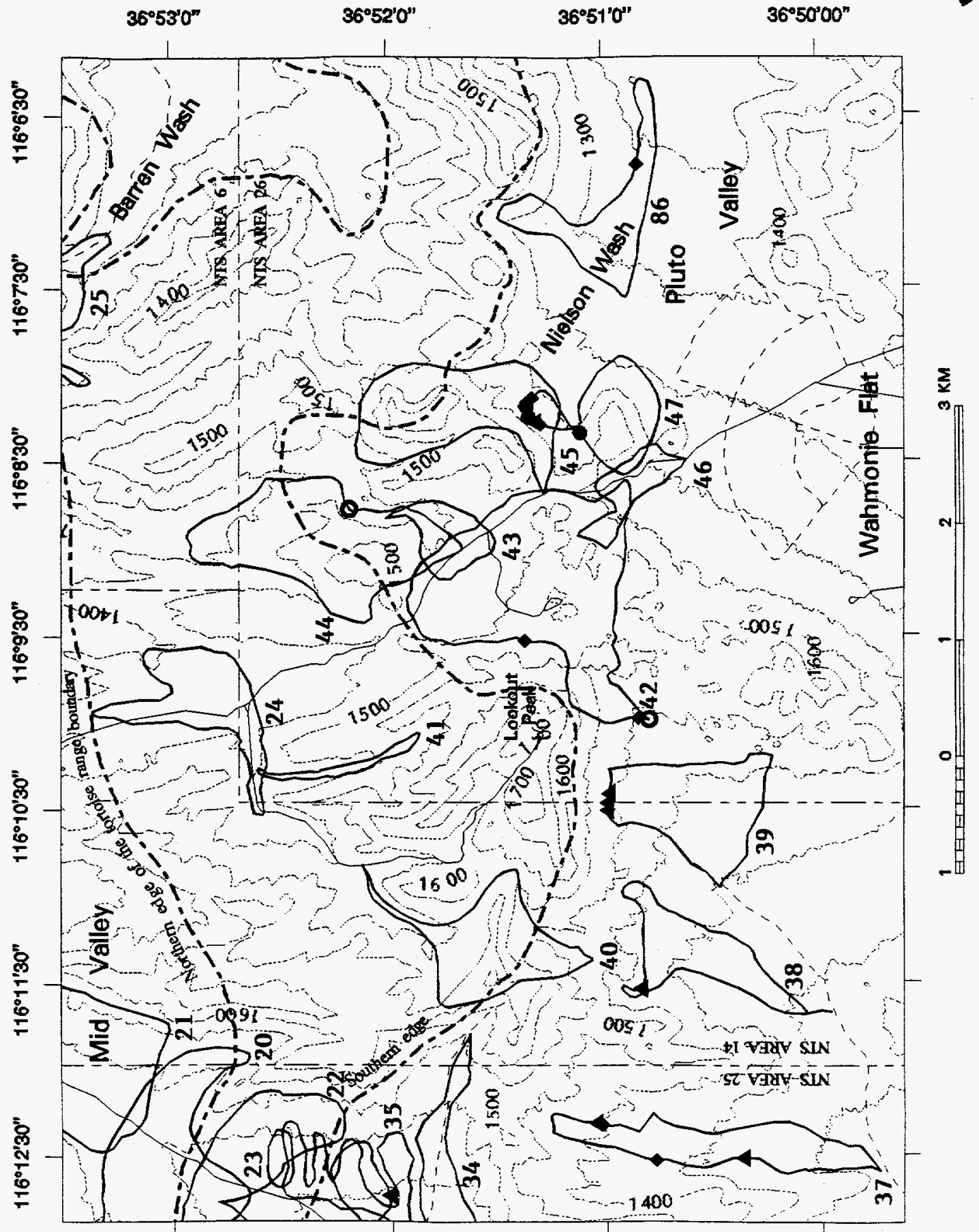

รू

量

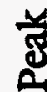

형

폴

붕

몰

怘苟

.

흥.드

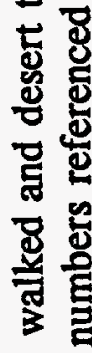

응

ญ

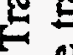

.

ri

쭐 는

合鸹 


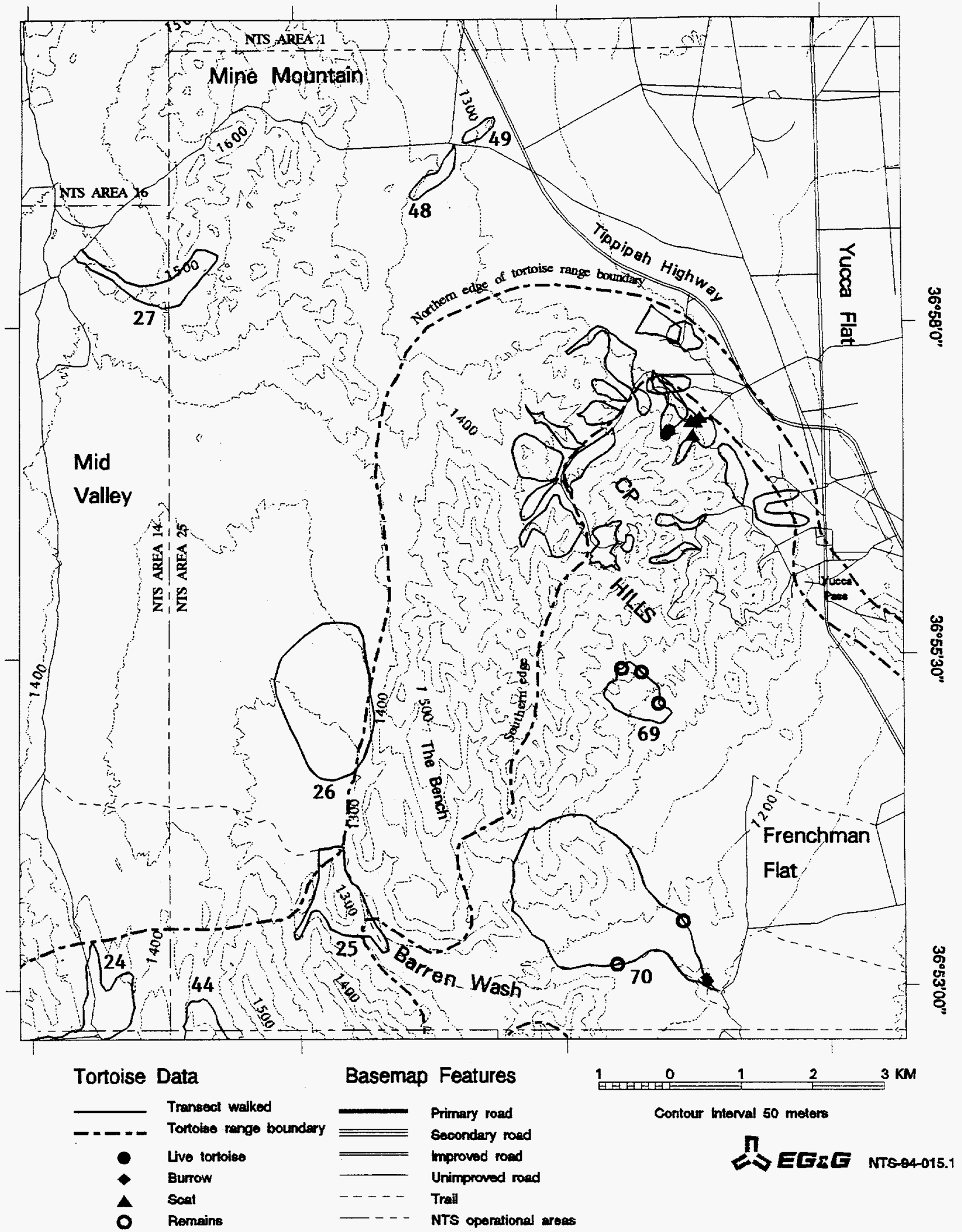

Appendix A4. Transects walked and desert tortoise sign found in Mid Valley and the CP Hills during 1993. Numbers adjacent to transects are the transect numbers referenced in the text. The unnumbered transects on the north slopes of the CP Hills are transects 50-68. 


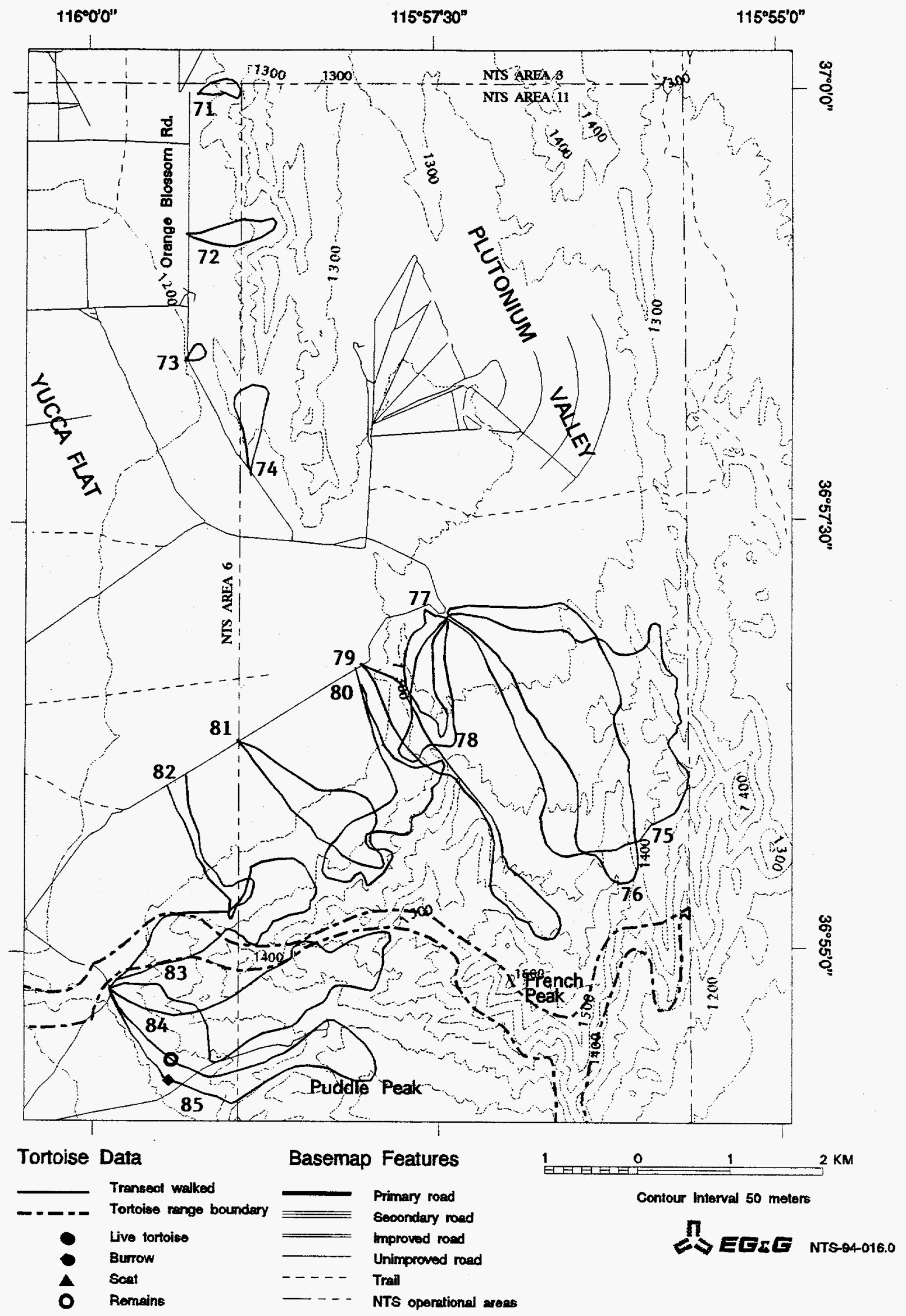

Appendix A5. Transects walked and desert tortoise sign found on Massachusetts Mountain, Yucca Flat, and Plutonium Valley during 1993. Numbers adjacent to transects are the transect numbers referenced in the text. 


\section{Literature Cited}

Barrett, S. L., and T. B. Johnson. 1990. Status summary for the desert tortoise in the Sonoran Desert. Unpublished report to U.S. Fish and Wildlife Service, Albuquerque, New Mexico. 115 pp.

Beatley, J. C. 1975. Climates and vegetation pattern across the Mojave/Great Basin Desert transition of southern Nevada. The American Midland Naturalist 93:53-70.

Beatley, J. C. 1976. Vascular plants of the Nevada Test Site and central-southern Nevada: ecologic and geographic distributions. U.S. National Technical Information Service, TID-26881, Springfield, Va. 308 pp.

EG\&G/EM (EG\&G Energy Measurements). 1991. The distribution and abundance of desert tortoises on the Nevada Test Site. U.S. Department of Energy Topical Report EGG 10617-2081. $41 \mathrm{pp}$.

Karl, A. 1981. The distribution and relative densities of the desert tortoise, Gopherus agassizii, in Lincoln and Nye counties, Nevada. Proceedings of the Desert Tortoise Council Symposium 1981:76-92.

Luckenbach, R. A. 1982. Ecology and management of the desert tortoise (Gopherus agassizii) in California. Pages 1-37 in R. B. Bury, editor. North American tortoises: conservation and ecology. U.S. Fish and Wildlife Service Wildlife Research Report 12. $126 \mathrm{pp}$.

O'Farrell, T. P., and L. A. Emery. 1976. Ecology of the Nevada Test Site: a narrative summary and annotated bibliography. U.S. Department of Energy Report NVO-167. $249 \mathrm{pp}$.

Schneider, P. B., R. J. Turner, and K. E. Bohuski. 1982. Distribution and relative density of desert tortoises at six selected sites in southern Nevada. Proc. Desert Tortoise Counc. Symp. 1982:36-50. 


\section{DISTRIBUTION LIST}

DOE/HQ

Office of Scientific Technical Information

DOE/NV

Technical Information Officer

D. R. Elle

DOE/YMP

W. R. Dixon

M. E. Ryder

EG\&G/EM

P. H. Zavattaro

Technical Information

Center

\section{EG\&G/EM NV Program}

J. A. Michael

T. P. O'Farrell

EG\&G/EM Remote Sensing Laboratory

S. L. Geherty

J. D. Pickus

\section{EG\&G/EM Environmental Sciences} Division

D. C. Anderson

K. R. Balzer

S. R. Blomquist

G. A. Brown

C. A. Callison

M. W. Fariss

R. G. Goodwin

R. A. Green

E. A. Holt

A. L. Hughes

T. T. Kato

T. A. Lindemann

G. E. Lyon

J. M. Mueller

W. K. Ostler

G. T. Sharp
EG\&G/EM ESD (continued)

C. L. Sowell

T. E. Walrath

C. A. Wills

V. K. Winkel

K. K. Zander

D. L. Rakestraw

K. R. Rautenstrauch

Reynolds Electrical \& Engineering Co., Inc.

R. B. Hunter

B. D. Woodward

P. D. Gregor

M. B. Saethre

U.S. Fish and Wildlife Service, Reno Field Office

D. L. Harlow

U.S. Fish and Wildlife Service, Las Vegas, NV

M. Collins

U.S. Fish and Wildlife Service, Desert Wildlife Refuge Complex, Las

Vegas, NV

K. Voget

Nevada Division of Wildlife, Region 3, Las Vegas, NV

M. Wickersham

Nevada Division of Wildlife, State Office, Reno

S. R. Albert

U.S. Bureau of Land Management, Las Vegas District Office

District Manager

Nellis Air Force Range, Las Vegas, NV

E. Hopper 